\title{
Pengaruh Jumlah Industri, Pertumbuhan Jumlah Penduduk dan Produktivitas Tanaman Padi terhadap Perubahan Jumlah Lahan Sawah di Kabupaten Indramayu Tahun 2011-2018
}

\author{
Risya Krisniawati*, Asnita Frida Sebayang \\ Prodi Ilmu Ekonomi, Fakultas Ekonomi dan Bisnis, Universitas Islam \\ Bandung, Indonesia. \\ *rkrisniawati@gmail.com, asnita@unisba.ac.id
}

\begin{abstract}
Productivity which results in a threat to food security. The challenges that exist in some of these areas occur in one of the areas that are the main rice production centers, namely Indramayu Regency. With the change in the number of rice fields it has resulted in a decrease in the amount of rice plant productivity thus threatening national food security. This study aims to measure the effect of the number of industries, population growth and productivity of rice crops on changes in the number of rice fields in Indramayu Regency in 2011-2018. This research data is secondary, namely data from the Statistics of Indramayu Regency with a sample size of 31 Districts in Indramayu Regency in 2011-2018. The analytical method used is quantitative with a panel data approach. This study uses panel data regression analysis with the Fix Effect Model (FEM) approach. The results of the research partially (t-test) show that the number of industries, population growth, and productivity of rice plants have a significant effect on the change in the number of rice fields in Indramayu Regency in 2011-2018. Simultaneously (f-test) the number of industries, population growth and rice productivity had a significant effect. The probability value of f-statistic for the independent variable is $(0.000000)$ smaller than the probability value $(0.05)$. This value shows that $\mathrm{H} 1$ is rejected. This shows that the number of industry (X1), population growth (X2) and productivity of rice plants (X3) together have an influence at the 0.05 significance level on changes in the number of rice fields.
\end{abstract}

Keywords: Number of rice fields, number of industries, population growth and productivity of rice crops.

Abstrak. Perubahan jumlah lahan sawah merupakan salah satu faktor pendorong dalam penurunan produktivitas pangan yang mengakibatkan adanya ancaman terhadap ketahanan pangan. Tantangan yang terdapat di beberapa daerah tersebut terjadi di salah satu wilayah yang menjadi sentra produksi padi utama yaitu Kabupaten Indramayu, Dengan adanya perubahan jumlah lahan sawah mengakibatkan penurunan jumlah produktivitas tanaman padi sehingga mengancam ketahanan pangan nasional. Penelitian ini bertujuan untuk mengukur pengaruh Jumlah Industri, Pertumbuhan Jumlah Penduduk dan Produktivitas Tanaman Padi terhadap Perubahan Jumlah Lahan Sawah di Kabupaten Indramayu Tahun 2011-2018. Data penelitian ini adalah sekunder, yaitu data yang berasal dari Badan Pusat Statistik Kabupaten Indramayu dengan jumlah sampel sebanyak 31 Kecamatan di Kabupaten Indramayu Tahun 2011-2018, Metode analisis yang digunakan adalah kuantitatif dengan pendekatan data panel. Penelitian ini menggunakan analisis regresi data panel dengan pendekatan Fix Effect Model (FEM). Hasil penelitian secara parsial (uji-t) menunjukan bahwa Jumlah Industri, Pertumbuhan Jumlah Penduduk, dan Produktivitas Tanaman Padi berpengaruh secara signifikan terhadap Perubahan Jumlah Lahan Sawah di Kabupaten Indramayu Tahun 2011-2018. Secara simultan (uji-f) Jumlah Industri, Pertumbuhan Jumlah Penduduk dan Produktivitas Tanaman Padi berpengaruh secara signifikan. nilai probilitas f-statistik untuk variabel bebas sebesar (0.000000) lebih kecil dibandingkan dengan nilai probabilitas (0.05). Nilai tersebut menunjukan bahwa H1 ditolak. Hal ini menunjukan bahwa jumlah Industri (X1), pertumbuhan jumlah penduduk (X2) dan produktivitas tanaman padi (X3) secara bersama-sama memiliki pengaruh pada tingkat signifikansi 0.05 terhadap perubahan jumlah lahan sawah.

Kata Kunci: Jumlah Lahan Sawah, Jumlah Industri, Pertumbuhan Jumlah Penduduk dan Produktivitas Tanaman Padi. 


\section{A. Pendahuluan}

Lahan sawah merupakan lahan yang paling banyak digunakan untuk kegiatan-kegiatan diluar non pertanian. Hal ini disebabkan karena luas lahan di sektor pertanian relatif lebih besar dibandingkan dengan luas lahan di sektor lainnya, sehingga lahan sawah dianggap sangat potensial mengalami perubahan jumlah lahan sawah untuk sektor non pertanian (Millar \& Roots, 2012). Lahan sawah menjadi sumber daya alam strategis bagi pembangunan. Hampir semua sektor pembangunan fisik memerlukan lahan, seperti sektor pertanian, kehutanan, perumahan, industri, pertambangan dan transportasi. Di bidang pertanian, lahan merupakan sumber daya yang sangat penting, baik bagi petani maupun bagi pembangunan pertanian. Hal ini didasarkan pada kenyataan bahwa di Indonesia kegiatan pertanian masih bertumpu pada lahan pertanian (Catur, 2016).

Permasalahan status rawan pangan dan penurunan jumlah lahan sawah terjadi pada wilayah yang selama ini berperan sebagai sentra produksi padi utama, yaitu Kabupaten Indramayu. Badan Ketahanan Pangan Daerah (BKPD) Provinsi Jawa Barat mencatat bahwa Kabupaten Indramayu merupakan daerah yang berstatus rawan, bahkan sangat rawan pangan. Tantangan yang terdapat di beberapa daerah Kabupaten tersebut meliputi adanya perubahan jumlah lahan sawah yang sangat tinggi, rata-rata kepemilikan lahan pertanian sempit, masih banyaknya jaringan irigasi yang tidak berfungsi (jabarprov.go.id, 2018).

Berdasarkan latar belakang yang telah diuraikan, maka perumusan masalah dalam penelitian ini sebagai berikut: "Bagaimana pengaruh jumlah industry, pertumbuhan jumlah penduduk dan produktivitas tanaman padi terhadap perubahan jumlah lahan sawah di Kabupaten Indramayu pada tahun 2011-2018”. Selanjutnya, tujuan dalam penelitian ini adalah untuk mengukur pengaruh jumlah industry, pertumbuhan jumlah penduduk dan produktivitas tanaman padi terhadap perubahan jumlah lahan sawah di Kabupaten Indramayu pada tahun 2011-2018.

\section{B. Metodologi Penelitian}

Jenis Penelitian yang digunakan oleh penulis yaitu jenis penelitian kuantitatif. Pada dasarnya menekankan analisis pada data-data numerikal (angka) yang diolah dengan metode statistik. Pendekatan kuantitatif dilakukan pada penelitian inferesial (dalam rangka pengujian hipotesis) dan menyandarkan kesimpulan hasilnya pada suatu probabilitas kesalahan penolakan hipotesis nihil. Metode yang dipakai dalam pengumpulan data adalah melalui studi pustaka. Studi pustaka merupakan teknik untuk mendapatkan informasi melalui catatan, literatur, dokumentasi dan lain-lain yang masih relevan dalam penelitian ini.

Data yang digunakan dalam penelitian ini adalah data sekunder. Data ini merupakan data yang diterbitkan oleh berbagai instansi yang berkompeten dengan permasalahan tersebut antara lain data Bappeda Kabupaten Indramayu, BPS Kabupaten Indramayu, Dinas Pertanian Kabupaten Indramayu serta berbagai data perubahan jumlah lahan sawah yang terjadi di Kabupaten Indramayu.

Penelitian ini menggunakan metode analisis regresi data panel. Data panel adalah gabungan dari data time series dan data cross section, dimana regresi dengan menggunakan data panel mempunyai observasi lebih banyak dengan data time series atau cross section saja (Gujarati \& Porter, 2009). Data panel memiliki keuntungan lebih informatif, lebih bervariatif dan lebih baik dalam melihat perubahan secara dinamis dari beberapa sektor dan dalam kurun waktu tertentu (Astuti, 2010). Proses analisis data dalam penelitian ini menggunakan alat bantu pengolah data yakni software E-views versi 11.0.

\section{Hasil Penelitian dan Pembahasan}

Data diolah dengan menggunakan metode analisis regresi data panel dengan periode waktu 2011-2018 dengan jumlah observasi data 31 Kecamatan di Kabupaten Indramayu. Hasil pemilihan model terbaik menggunakan fixed effect model. Adapun hasil pemilihan model sebagai berikut : 


\section{Hasil pemilihan model regresi data panel}

- Uji Chow

Berdasarkah hasil Uji Chow, diperoleh hasil nilai probabilitas 0.0000 yang artinya nilai probabilitas di atas kurang dari nilai signifikansi $5 \%(0.0000 \leq \alpha 0.05)$ atau Ho ditolak dan Fixed Effect Model (FEM) yang digunakan pada Kabupaten Indramayu.

- Uji Hausman

Berdasarkah hasil Uji Hausman di atas, pada Kabupaten Indramayu diperoleh hasil nilai probabilitas 0,0000 yang artinya nilai signifikansi $5 \%(0.0000 \leq \alpha 0.05)$ atau Ho ditolak dan Fixed Effect Model (FEM) yang digunakan pada Kabupaten Indramayu.

\section{Pengujian asumsi klasik}

a. Uji Multikulioneritas

Multikulioneritas menunjukkan adanya hubungan antara variabel-variabel bebas pada persamaan yang memiliki lebih dari satu variabel independen atau regresi berganda yang menandakan adanya kesalahan pada sebuah uji asumsi klasik (Syarifah, 2020).

Tabel 1. Uji Multikulioneritas

\begin{tabular}{|c|c|c|c|}
\hline & $\begin{array}{c}\text { jumlah } \\
\text { industri }\end{array}$ & $\begin{array}{c}\text { pertumbuhan jumlah } \\
\text { penduduk }\end{array}$ & $\begin{array}{c}\text { produktivitas } \\
\text { tanaman padi }\end{array}$ \\
\hline $\begin{array}{c}\text { jumlah industri } \\
(\mathrm{x} 1)\end{array}$ & 1.0000 & -0.1353 & -0.3075 \\
\hline $\begin{array}{c}\text { pertumbuhan } \\
\text { jumlah penduduk } \\
(\mathrm{x} 2)\end{array}$ & -0.1353 & 1.0000 & 0.0337 \\
\hline $\begin{array}{c}\text { produktivitas } \\
\text { tanaman padi (x3) }\end{array}$ & -0.3075 & 0.0337 & 1.0000 \\
\hline
\end{tabular}

Sumber: Data Sekunder Diolah Menggunakan E-Views 11.0 Tahun 2021

Tabel diatas menunjukan bahwa tidak terdapat korelasi antar variabel yang melebihi 0.80 , artinya model regresi tersebut terbebas dari masalah multikulioneritas.

b. Uji Heteroskedastisitas

Menurut (Ghazali, 2011) pengujian heterokedastisitas memiliki kriteria yaitu jika tingkat signifikan di atas $5 \%$, berarti tidak terdapat gejala heterokedastisitas tetapi jika di bawah tingkat signifikan $5 \%$ maka terjadi gejala heterokedastisitas.

Tabel 2. Uji Heteroskedastisitas

\begin{tabular}{|c|c|c|c|}
\hline variable & coefficient & std. error & t-statistic \\
\hline $\mathrm{c}$ & 18.91953 & 4.431419 & 4.269408 \\
\hline jumlah industri (x1) & -0.000717 & 0.000940 & -0.762738 \\
\hline $\begin{array}{c}\text { pertumbuhan jumlah } \\
\text { penduduk (x2) }\end{array}$ & 0.008740 & 0.20850 & 0.419207 \\
\hline $\begin{array}{c}\text { produktivitas } \\
\text { tanaman padi (x3) }\end{array}$ & -0.155736 & 0.059925 & -2.598861 \\
\hline
\end{tabular}

Sumber: Data Sekunder Diolah Menggunakan E-Views 11.0 Tahun 2021

Berdasarkan tabel diatas, tingkat signifikansi variabel bebas berada di atas nilai 0.05 yang artinya tidak terdapat masalah multikulioneritas pada persamaan regresi.

c. Uji Autokorelasi

Pengujian Autokorelasi dapat dilihat dengan menggunakan Uji Durbin- Waston (Dw Test). Uji Autokorelasi bertujuan untuk model regresi ada korelasi kesalahan pengganggu pada periode $t$ dengan kesalahan pada periode sebelumnya (t-1). Pengujian autokorelasi dapat dilihat dengan menggunakan uji Durbin-Watson (Dw Test). Menurut (Santoso, 2012), kriteria ada atau tidaknya korelasi adalah jika nilai Dw terletak diantara -2 sampai +2 berarti maka tidak ada autokorelasi. 
Tabel 3. Uji Autokorelasi

\section{Durbin-Watson stat $\quad 0.212503$}

Sumber : Data Sekunder Diolah Menggunakan E-Views 11.0 Tahun 2021

Berdasarkan data di atas nilai Dw adalah 0.212503 yang artinya nilai tersebut lebih dari -2 yang berarti tidak terjadi masalah autokorelasi pada persamaan regresi.

\section{Uji Statistik}

a. Koefisien Determinasi $\left(\mathrm{R}^{2}\right)$

Berdasarkan hasil dari perhitungan menunjukkan R2 sebesar 0.917095 Nilai tersebut berarti 91,7 \% variasi pada jumlah industri, pertumbuhan jumlah penduduk, dan produktivitas tanaman padi. Sedangkan sisanya dipengaruhi variabel lain di luar model.

b. Uji t berikut:

Berdasarkan hasil data di atas maka dapat dijelaskan dengan tingkat $\alpha 0.05$ sebagai

- Pada koefisien variabel Jumlah Industri (X1) menunjukkan tingkat signifikansi 0.0000 $(<0.05)$ yang artinya variabel Jumlah Industri (X1) berpengaruh secara negatif dan signifikan terhadap perubahan jumlah lahan sawah di Kabupaten Indramayu Tahun 2011-2018

- Pada koefisien variabel Pertumbuhan Jumlah Penduduk (X2) menunjukkan tingkat signifikansi $0.0003(<0.05)$ yang artinya Pertumbuhan Jumlah Penduduk berpengaruh secara negatif signifikan terhadap perubahan jumlah lahan sawah di Kabupaten Indramayu Tahun 2011-2018.

- Pada koefisien variabel Produktivitas tanaman Padi (X3) menunjukkan tingkat signifikansi $0.0000(<0.05)$ yang artinya variabel produktivitas tanaman Padi (X3) berpengaruh secara positif signifikan terhadap perubahan jumlah lahan sawah di Kabupaten Indramayu Tahun 2011-2018.

c. Uji f

Nilai probabilitas $\mathrm{f}$ hitung < $\mathrm{f}$ tabel artinya $\mathrm{H} 1$ ditolak dan variabel bebas yaitu jumlah Industri, pertumbuhan jumlah penduduk, dan produktivitas tanaman padi secara bersama-sama memiliki pengaruh pada tingkat signifikansi 0.05 terhadap perubahan jumlah lahan sawah di Kabupaten Indramayu Tahun 2011-2018.

d. Hasil estimasi model

Tabel 4. Hasil Estimasi Model

\begin{tabular}{|c|c|c|c|c|}
\hline Variable & Coefficient & Std. Error & t-Statstic & Prob \\
\hline C & -7.467 .853 & 1.465447 & -0.509596 & 0.6109 \\
\hline Jumlah Industri & -0.033557 & 0.011295 & -2.970965 & 0.0033 \\
\hline $\begin{array}{c}\text { Pertumbuhan } \\
\text { Jumlah Penduduk }\end{array}$ & -0.656347 & 0.102754 & -6.387566 & 0.0000 \\
\hline $\begin{array}{c}\text { Produktivitas } \\
\text { Tanaman Padi }\end{array}$ & 0.725215 & 0.130197 & 5.570147 & 0.0000 \\
\hline
\end{tabular}

Sumber: Data Sekunder Diolah Menggunakan E-Views 11.0 Tahun 2021

Berdasarkan hasil estimasi diatas, maka persamaan model dari variabel pengaruh jumlah industri. Pertumbuhan jumlah penduduk dan produktivitas tanaman padi terhadap perubahan jumlah lahan sawah di Kabupaten Indramayu sebagai berikut:

PERUBAHAN JUMLAH LAHAN SAWAH $=-0.033557$ (JUMLAH INDUSTRI) 0.656347 (PERTUMBUHAN JUMLAH PENDUDUK) + (PRODUKTIVITAS TANAMAN PADI) + eit 


\section{Analisis Ekonomi}

a. Pengaruh Jumlah Industri Terhadap Perubahan Jumlah Lahan Sawah

Dalam penelitian yang telah dilakukan, hasil model regresi membuktikan bahwa jumlah industri berpengaruh secara negatif dan signifikan terhadap besarnya perubahan jumlah lahan sawah di Kabupaten Indramayu. Besarnya nilai koefisien parameter jumlah industri sebesar 0,3355 , ini berarti bahwa jika jumlah industri meningkat sebanyak 1unit usaha maka akan diikuti dengan penurunan jumlah lahan sawah sebesar -0,3355 Ha.

Hal ini sesuai dengan penelitian Annisa Titias Habibatussolikhah, Darsono \& Susi Wuri Ani (2016), hasil penelitian ini menunjukkan adanya pengaruh signifikan antara variabel jumlah industri terhadap perubahan jumlah lahan sawah yang terdapat di Kabupaten Indramayu.

b. Pengaruh Pertumbuhan Jumlah Penduduk Terhadap Perubahan Jumlah Lahan Sawah

Pada penelitian yang telah dilakukan membuktikan bahwa variabel pertumbuhan jumlah penduduk berpengaruh signifikan dan negatif terhadap perubahan jumlah lahan sawah. Variabel pertumbuhan jumlah penduduk memiliki koefisien sebesar -0,6553. Hasil model regresi menunjukkan bahwa dengan adanya peningkatan pertumbuhan jumlah penduduk sebesar 1 persen maka perubahan jumlah lahan sawah akan mengalami penurunan sebesar -0,6553 Ha.

Hal ini sesuai dengan penelitian Irwan Wunarlan \& Hasbullah Syaf (2019). Dimana variabel pertumbuhan jumlah penduduk memiliki pengaruh terhadap variabel perubahan jumlah lahan sawah dan memiliki hubungan yang negatif. Hubungan antara pertumbuhan jumlah penduduk terhadap variabel perubahan jumlah lahan sawah. Meskipun terjadi hubungan negatif pada pertumbuhan jumlah penduduk tetap akan menyebabkan adanya perubahan lahan sawah.

c. Pengaruh Produktivitas Tanaman Padi Terhadap Perubahan Jumlah Lahan Sawah

Pada penelitian yang telah dilakukan membuktikan bahwa variabel produktivitas tanaman padi berpengaruh signifikan dan positif terhadap perubahan jumlah lahan sawah. Variabel produktivitas tanaman padi memiliki koefisien sebesar 0,7152. Hasil model regresi menunjukkan bahwa dengan adanya peningkatan produktivitas tanaman padi sebesar $1 \mathrm{t} / \mathrm{Ha}$ maka akan diikuti dengan peningkatan perubahan jumlah lawan sebesar 0,7152 t/Ha.

Hal ini sejalan dengan penelitian yang dilakukan oleh Anugrah (2005), hasil penelitian tersebut menunjukkan bahwa semakin tinggi tingkat produktivitas tanaman padi maka akan semakin kecil penurunan luas lahan sawah yang terjadi. Selain dampak kerugian yang akan diderita akibat terjadinya konversi lahan sawah. Koefisien parameter produktivitas lahan sawah yang bertanda negatif dan berpengaruh nyata, dapat diartikan bahwa masih adanya kecenderungan dari petani untuk mempertahankan lahan sawah yang memiliki produktivitas yang tinggi. Produktivitas tanaman padi yang tinggi ternyata cukup efektif untuk mengendalikan laju konversi lahan sawah ke penggunaan non pertanian.

\section{Kesimpulan}

Berdasarkan pembahasan dalam penelitian ini, peneliti menyimpulkan beberapa hasil penelitian sebagai berikut:

1. Hasil perhitungan koefisien determinasi $\left(\mathrm{R}^{\wedge} 2\right)$ sebesar 0.9171 mengindikasikan bahwa variabel jumlah industri, pertumbuhan jumlah penduduk, dan produktivitas tanaman padi memiliki pengaruh sebesar $91,71 \%$ yang dapat dijelaskan dalam persamaan model, untuk sisanya sebesar 9,3\% dipengaruhi oleh variabel lain di luar model.

2. Besarnya koefisien variabel jumlah Industri sebesar -0.0335 , artinya ketika terjadi peningkatan jumlah industri sebesar 1 unit maka akan mengakibatkan penurunan jumlah lahan sawah di Kabupaten Indramayu sebesar 0.0335 Ha.

3. Besarnya koefisien variabel Pertumbuhan Jumlah Penduduk sebesar -0.6563 , artinya ketika terjadi peningkatan jumlah penduduk sebesar $1 \%$ maka akan mengakibatkan penurunan jumlah lahan sawah di Kabupaten Indramayu sebesar $0.6563 \mathrm{Ha}$.

4. Besarnya koefisien variabel produktivitas tanaman padi sebesar 0.7252 , artinya ketika produktivitas padi mengalami peningkatan sebesar $1 \mathrm{t} / \mathrm{Ha}$ maka akan diikuti dengan peningkatan jumlah lahan sawah sebesar $0.7252 \mathrm{Ha}$. 
5. Pengujian secara parsial (uji-t) menunjukan bahwa jumlah industri, pertumbuhan jumlah penduduk dan produktivitas tanaman padi berpengaruh secara signifikan terhadap perubahan jumlah lahan sawah dan dengan pengujian secara simultan (uji-f) menunjukan bahwa jumlah industri, pertumbuhan jumlah penduduk dan produktivitas tanaman padi berpengaruh secara Bersama-sama terhadap perubahan jumlah lahan sawah.

\section{Acknowledge}

Peneliti mengucapkan terimakasih banyak kepada pihak Universitas islam Bandung dan Badan Pusat Statistik Jawa Barat yang telah mendukung dan membantu dalam menyelesaikan tulisan ini. Serta tak lupa terimakasih banyak juga kepada Dr. Asnita Frida Sebayang S.E., M.Si dan Ria Haryatiningsih S.E., M.T. yang telah membimbing dan memberikan arahan agar terselesaikannya tulisan ini.

\section{Daftar Pustaka}

[1] Abdurachmat, I Dan Maryani, E. (1998). Geografi Ekonomi (Diktat Kuliah). Bandung: Jurusan Pendidikan Geografi FPIPS IKIP Bandung

[2] Adipka, A. (2018). Analisis Perubahan Penggunaan Lahan Persawahan Di Kota Metro Antara Tahun 2000-2015. 49-62.

[3] Anugrah K, F. (2015). Analisis faktor-faktor yang mempengaruhi konversi Lahan sawah ke penggunaan non pertanian Di kabupaten tangerang. 29-42.

[4] Astuti, R. (2015). Analisis determinan ketimpangan distribusi pendapatan di daerah istimewa yogyakarta periode 2005-2013. 46-61.

[5] Arsyad, Lincolin. 2001. Ekonomi Pembangunan. Edisi Ke-Empat. Penerbit STIE YKPN. Yogyakarta.

[6] Badan Pusat Statistik Kabupaten Indramayu, 2019. Kabupaten Indramayu Dalam Angka Tahun 2019. Badan Pusat Statistik Kabupaten Indramayu, Indramayu, 2019

[7] Badan Pusat Statistik Kabupaten Indramayu, 2011. Kabupaten Indramayu Dalam Angka Tahun 2011. Badan Pusat Statistik Kabupaten Indramayu, Indramayu, 2011.

[8] Badan Pusat Statistik Provinsi Jawa Barat, 2019. Kabupaten Indramayu Dalam Angka Tahun 2019. Badan Pusat Statistik Kabupaten Indramayu, Indramayu, 2019.

[9] Budihari, N. (2016). Perubahan Fungsi Lahan Pertanian Menjadi Perumahan Berdampak Terhadap Sosial Ekonomi Di Desa Bongan Kecamatan Kediri Kabupaten Tabanan. 32-46.

[10] Fathurakhman, J. (2016). Analisis perubahan penggunaan lahan sawah menjadi permukiman di kabupaten pringsewu Tahun 2012-2014. 26-37.

[11] Firman, T. (2005). Urbanisasi, Persebaran Penduduk, Dan Tata Ruang Di Indonesia. Artikel Laporan Penelitian IPB.

[12] Hidayat, Y., Ismail, A., \& Ekayani, M. (2017). Dampak konversi lahan pertanian terhadap ekonomi Rumah tangga petani padi (Studi Kasus Kecamatan Kertajati Kabupaten Majalengka Jawa Barat). Jurnal Pengkajian dan Pengembangan Teknologi Pertanian, 171182.

[13] Husna, R., Azhar, \& Marsudi, E. (2018). Faktor-faktor yang mempengaruhi alih fungsi lahan sawah di kabupaten aceh besar. Jurnal Ilmiah Mahasiswa Pertanian, 525-533.

[14] Ibrahim, J.T. (2002). Sosiologi Pedesaan. Malang: Universitas Muhammadiyah Malang Press.

[15] Irawan, Bambang Dan Supeno Friyanto. (2002). "Dampak Konversi Lahan Sawah Di Jawa Terhadap Produksi Beras Dan Kebijakan Pengendaliannya". Bogor: Badan Penelitian Dan Pengembangan Pertanian RI, Bogor.

[16] Jannah, R., Eddy, B. T., \& Dalmiyatun, T, (2017). "Alih Fungsi Lahan Pertanian Dan Dampaknya Terhadap Kehidupan Penduduk Di Kecamatan Sayung Kabupaten Demak". Agrisocionomics: Jurnal Sosial Ekonomi Pertanian, 1(1), 1-10.

[17] Kamilah, A. (2017). Analisis ekonomi alih fungsi lahan pertanian di kota bekasi (kasus kecamatan bekasi utara dan Bantar gebang). Jurnal Agribisnis dan Pengembangan Wilayah 
Vol. 5 No. 1, 36-49.

[18] Kertasapoetra G. (1987). Pembentukan Perusahaan Industri. Jakarta: Bina Aksara

[19] Mahananto, Sutrisno, S., \& Ananda, C. (2016). Faktor-faktor yang mempengaruhi produksi padi Studi kasus di kecamatan nogosari, boyolali, jawa tengah. Jurnal Wacana, 179-191.

[20] Muhammad Iqbal Dan Sumaryanto, (2007) "Strategi Pengendalian Alih Fungsi Lahan Pertanian Bertumpu Pada Partisipasi Masyarakat". Bogor: Pusat Analisis Sosial Ekonomi Dan Kebijakan Pertanian

[21] Nugroho, A. (2017). Perubahan Penggunaan Lahan Sawah Menjadi Non Sawah dan Pengaruhnya Terhadap Keberlanjutan Sawah Lestari Di Kabupaten Klaten. vol.6 no.2.

[22] Nurpita, A., Wihastuti, L., \& Andjani, I. Y. (2018). Dampak Alih Fungsi Lahan Terhadap Ketahanan Pangan Rumah Tangga Tani Di Kecamatan Temon, Kabupaten Kulon Progo. Jurnal Gama Societa, 1(1), 103-110.

[23] Perroux, François (1955), "Note Sur La Notion De Poles Croissance. Economic Appliquee”, $1 \& 2: 307-320$.

[24] Purbani, D. (2013). Perubahan Penggunaan Lahan Pesawahan Menjadi Lahan Terbangun Di Kabupaten Karawang. 39-58.

[25] Prasada, I., \& Rosa, T. (2018). Dampak alih fungsi lahan sawah terhadap ketahanan pangan di daerah istimewa yogyakarta. Jurnal Sosial Ekonomi Pertahanan Vol.4 no.3, 210-224.

[26] Prasetyo, R. B. (2010). Dampak Pembangunan Infrastruktur Dan Aglomerasi Industri Terhadap Pertumbuhan Ekonomi Regional Di Indonesia.

[27] Rahmi, R., Suratiyah, K., \& Mulyo, J. (2014). Ketahanan Pangan Rumah Tangga Petani Kecamatan Ponjong Kabupaten Gunung Kidul . Jurnal Agro Ekonomi Vol.4 no.2 , 190-201.

[28] Linda Dwi Rohmadiani. (2011). Dampak Konversi Lahan Pertanian Terhadap Kondisi Sosial Ekonomi Petani (Studi Kasus: Jalur Pantura Kecamatan Pamanukan Kabupaten Subang). Jurnal Teknik WAKTU, 09(02), 71-81. https://doi.org/ISSN : 1412 - 1867

[29] Saleh, Irsan Azhari, (1986), Industri Kecil Sebuah Tinjauan Dan Perbandingan, LP3ES, Jakarta

[30] Santosa, S. P. (2017). Kajian Ketersediaan Dan Kebutuhan Konsumsi Beras Di Kabupaten Karanganyar, Jawa Tengah. Jurnal Bumi Indonesia, 6(4), 3-11.

[31] Setyawati, E.A. (2002), "Pengaruh Kegiatan Operasi Kawasan Industri Terhadap Perkem- Bangan Sosial Ekonomi Masyarakat Pedesaan” Skripsi, Jurusan Ilmu-Ilmu Sosial Ekonomi Pertanian Fakultas Pertanian, IPB.

[32] Suharyanto, Mahaputra, K., Ngurah Arya, N., \& Rinaldy, J. (2016). Faktor Penentu Alih Fungsi Lahan Sawah Di Tingkat Rumah Tangga Petani dan Wilayah di Provinsi Bali. Jurnal Pengkajian dan Pengembangan Teknologi Pertanian, 9-22.

[33] Sukesi, K., \& Shinta, A. (2011). Diversifikasi Pangan Sebagai Salah Satu Strategi Peningkatan Gizi Berkualitas Di Kota Probolinggo ( Studi Kasus Di Kecamatan Kanigaran ). SEPA, 7(2), 85-90.

[34] Suratha, I. (2014). Dampak alih fungsi lahan pertanian terhadap ketahanan pangan. Jurnal Media Komunikasi Geografi, 52-61.

[35] Tb, Catur, Joko Purwanto, Rhina Uchyani F Dan Susi Wuri Ani. (2010) "Dampak Alih Fungsi Lahan Pertanian Ke Sektor Non Pertanian Terhadap Ketersediaan Beras Di Kabupaten Klaten Provinsi Jawa Tengah". Semarang: Jurusan Agribisnis Fakultas Pertanian UNS.

[36] Wahed, M. (2015). Pengaruh Luas Lahan, Produksi, Ketahanan Pangan dan Harga Gabah Terhadap Kesejahteraan Petani Padi di Kabupaten Pasuruan. Jesp, 7(1), 68-74.

[37] Widiatmaka. (2017). Analisis spasial perubahan penggunaan lahan pertanian untuk Mendukung kemandirian pangan di kabupaten indramayu. Jurnal Ilmiah Globe, 175-184. 